\title{
Analisis Kenyamanan Pencahayaan Alami di Ruang Kelas SMKN 2 Bandar Lampung
}

\author{
Farhan Giano Indrakesuma ${ }^{1}$, Ai Siti Munawaroh ${ }^{2}$ \\ e-mail: farhangianoindrakesuma@gmail.com ${ }^{1}$,aisiti.arch@ubl.ac.id ${ }^{2}$ \\ Prodi Arsitektur Fakultas Teknik Universitas Bandar Lampung ${ }^{1,2}$
}

\begin{abstract}
Abstrak
Ruang kelas merupakan tempat berlangsungnya kegiatan belajar mengajar siswa dan guru yang selalu rutin dilaksanakan setiap hari sehingga perlunya pencahayaan yang ideal untuk kegiatan belajar yang baik. Namun kenyataan di lapangan masih banyak ruang kegiatan belajar mengajar yang tidak memenuhi syarat standar pencahayaan ruang kelas yaitu 250 lux. Penelitian ini bertujuan untuk mengetahui keadaan pencahayaan ruang kelas yang ada di SMKN 2 Bandar Lampung. Metode penelitian menggunakan metode survey lapangan dengan alat pengukuran Luxmeter. Hasilnya ditemukan ruang kelas tersebut masih belum memenuhi standar karena pencahayaan yang terjadi kurang atau lebih dari standar yang ditetapkan, yang dipengaruhi oleh faktor sekitar berupa vegetasi dan bangunan yang ada.Penelitian lebih lanjut diperlukan untuk mencari tahu solusinya.
\end{abstract}

Kata Kunci : Kenyamanan Visual, Pencahayaan, Ruang Kelas, Distribusi, Bukaan Ruang

\section{Abstract}

The classroom is a place for teaching and learning activities for students and teachers which are routinely carried out every day so that ideal lighting is needed for good learning activities. However, the reality in the field is that there are still many teaching and learning activities that do not meet the standard classroom lighting requirements, which is 250 lux. This study aims to find out the state of the classrooms in SMKN 2 Bandar Lampung. The research method uses a descriptive quantitative approach. The results found that the classrooms were still below standard and further research was needed to find out other solutions.

Keywords : Visual Comfort, Lighting, Classroom, Distribution, Space Opening

\section{Pendahuluan}

Kualitas kenyamanan visual selalu menjadi elemen penting kenyamanan manusia. Di ruang kelas, pencahayaan memainkan peran kunci dalam kinerja siswa karena mereka berada di sekolah dalam jangka waktu yang lama dan melaksanakan aktivitas yang melibatkan upaya mental dan konsentrasi sebagai bagian dari proses pembelajaran mereka (Noda, Lima, Souza, Leder, \& Quirino, 2020). 
Salah satu prioritas tertinggi dalam mendesain bangunan secara umum adalah meminimalisir sebisa mungkin pemakaian energi yang ada dan dapat memaksimalkan penggunaan energi alami sebisa mungkin untuk memenuhi kebutuhan sehari-hari (Bakmohammadi \& Noorzai, 2020). Selain itu, rasa nyaman dari pengguna ruang tersebut juga akan mempengaruhi produktivitas dari hal yang ia lakukan. Karenanya, ruang kelas belajar yang terdesain dengan baik akan membantu proses belajar mengajar menjadi lebih optimal, seperti ruang kelas yang dapat memanfaatkan cahaya alami dengan baik untuk proses belajar akan sangat membantu menghemat energi dan juga membuat proses belajar jadi lebih baik. Salah satu faktor kenyamanan visual sebuah ruang didapat oleh jumlah cahaya yang masuk yang dimana dipengaruhi beberapa faktor internal dan eksternal seperti luas bukaan, jumlah, dan penempatan bukaan, serta cuaca, vegetasi, dan bangunan disekitarnya(Yuniar, Dwicahyo, Harmanda, Putra, \& Wijaya, 2014).

Besaran standar cahaya untuk ruang kelas adalah 250 lux hingga 300 lux berdasarkan standar nasional Indonesia (SNI, 2000), namun keadaan di lapangan tidak demikian, karena masih banyak ruangan yang belum memenuhi standar yang ditetapkan, seperti pada penelitian di ruang kuliah Fakultas teknik UNHAS tidak memenuhi standar (Amin, Jamala, \& Luizjaya, 2016), penelitian di kelas Jurusan Fisika FMIPA Unsrat mencakup empat ruang perkuliahan juga mendapati semuanya tidak memenuhi standar yang berlaku, yaitu masih dibawah standar 250 lux(Tongkukut, 2016). Penelitian ini dilaksanakan untuk mencari tahu apakah ruang kelas di Bandar Lampung sudah memenuhi standar atau belum.

\section{Metode Penelitian}

Penelitian ini dilakukan pada tanggal 16 November 2020 sampai dengan 20 November 2020 dengan tujuan untuk mengetahui seperti apa suasana di ruang kelas SMKN 2 Bandar Lampung, keadaan iklim dan cuaca yang terjadi, faktor-faktor yang mempengaruhi pencahayaan, dan besaran cahaya yang terjadi di dalam ruang kelas SMKN 2 Bandar Lampung.

Metode yang akan digunakan dalam penelitian yaitu penelitian survey dengan melakukan pengkuran langsung di lapangan. Pengukuran akan menggunakan alat yang sudah disiapkan yaitu alat ukur cahaya berupa Luxmeter.

\section{Lux Meter HS1010}

Yaitu alat yang mampu mengukur mengetahui serta mengukur seberapa besar intensitas cahaya yang ada di suatu tempat. Lux Meter HS1010 memiliki fitur seperti:

- Rentang pengukuran luas dengan akurasi tinggi;

- Pemilihan tingkat pengukuran otomatis;

- Pengukuran maks dan min;

- Pemilihan unit LUX / FC;

- Data terus;

- Perekaman otomatis data. 


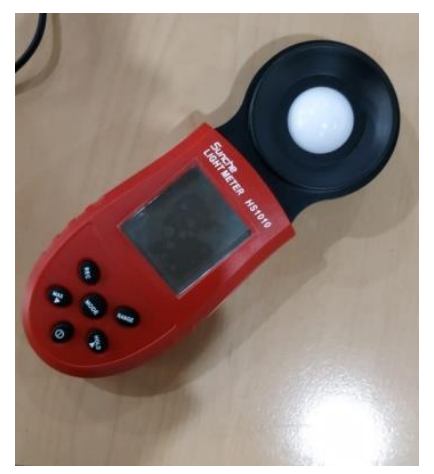

Gambar1.Lux Meter HS1010 (Dokumentasi, 2020)

\section{Lokasi Penelitian}

Penelitian ini dilakukan pada dua ruang kelas yang ada di dua gedung yang saling berseberangan yang keduanya terletak di kawasan SMKN 2 Bandar Lampung, yang beralamatkan di JI. Prof. Dr. Ir. Sumantri Brojonegoro No.1, Gedong Meneng, Kec. Rajabasa, Kota Bandar Lampung, Lampung 35141.

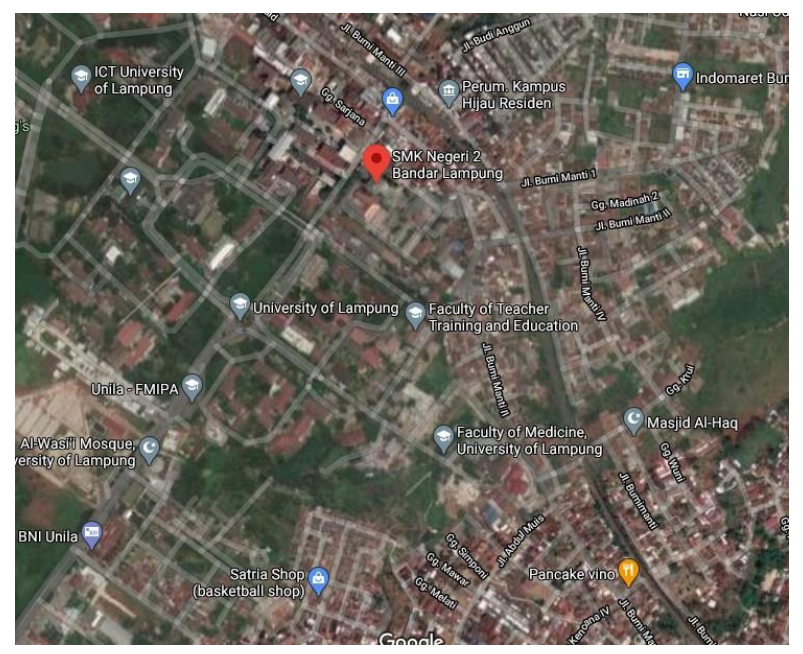

Gambar2.Peta Lokasi SMKN 2 Bandar Lampung (Google Maps, 2020)

Lokasi penelitian ini berbatasan dengan:

Utara : Berbagai rumah makan

Selatan : Bangunan FKIP Unila

Timur : Pemukiman warga

Barat : Bangunan FISIP Unila

\section{Objek Penelitian}

Objek yang diteliti dalam penelitian kenyaman visual pencahayaan ini adalah ruang kelas. Yaitu Ruang Kelas 1 dan Ruang Kelas 2. Alasan memilih kedua lokasi tersebut karena merupakan dua ruang kelas yang keduanya terletak di tengah gedung bangunan dan saling berhadapan, serta ruangnya memiliki fungsi yang sama sebagai ruang belajar mengajar dan kedua ruang kelas tersebut setara.

Berikut adalah foto Site Plan, Ruang Kelas 1 dan Ruang Kelas 2: 


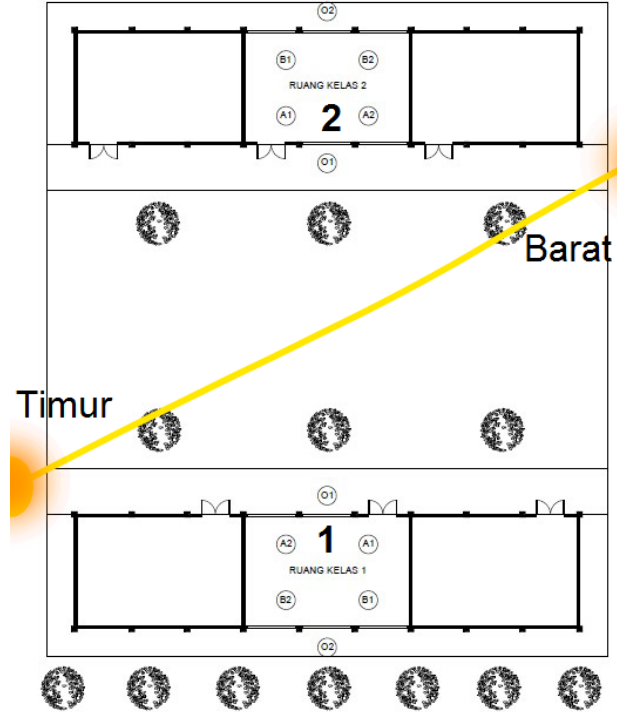

Gambar3.Site Plan Bangunan Kelas (Pribadi, 2020)

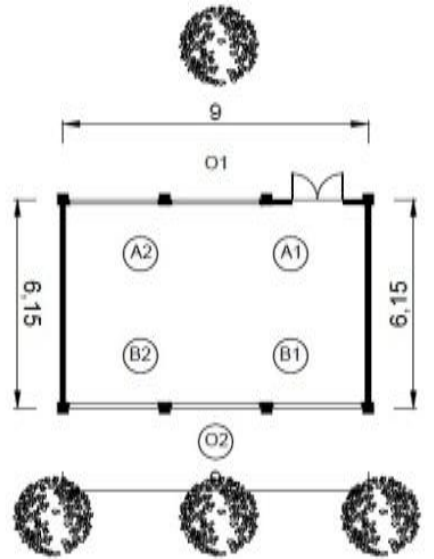

Gambar4.Denah Ruang Kelas 1 (Pribadi, 2020)

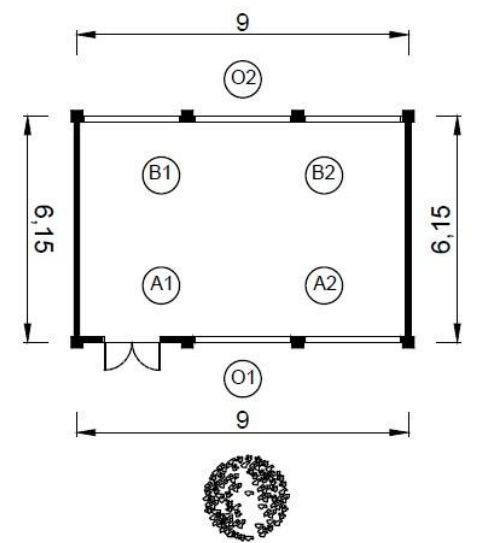

Gambar5.Denah Ruang Kelas 2 (Pribadi, 2020) 


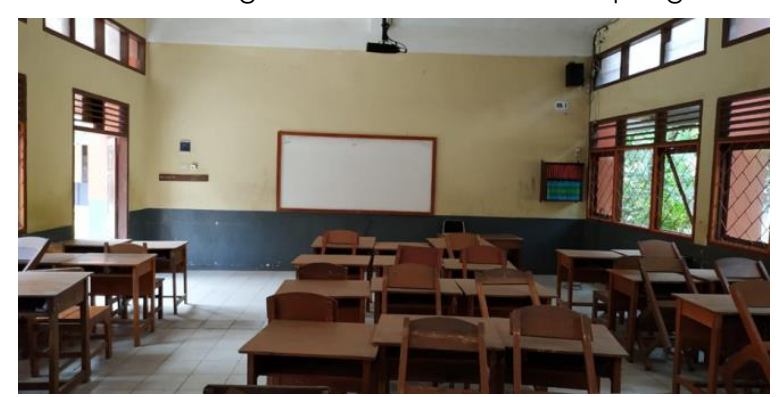

Gambar6.Foto Suasana Ruang Kelas 1 (Dokumentasi, 2020)

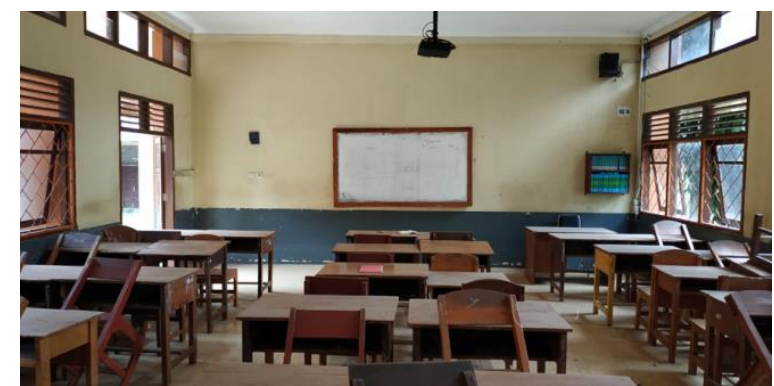

Gambar7.Foto Suasana Ruang Kelas 2 (Dokumentasi,2020)

Selama penelitian, tidak ada kegiatan belajar mengajar. Dalam penelitian berlangsung beberapa kali terjadi cuaca hujan sehingga disaat itu data pencahayaan yang masuk ke ruang pun juga kecil. Dikarenakan keadaan tidak ada pengguna ruang, maka penelitian hanya dilakukan dalam bentuk pengukuran dan observasi ke lapangan seperti apa keadaan pencahayaan di kedua kelas tersebut.

Penelitian ini dilakukan selama seminggu dari hari Senin hingga Jumat pada tanggal 16 November hingga 20 November 2020. Ditiap kelasnya ada 4 titik pengukuran di dalam kelas yaitu A1, A2, B1, B2, dan di luar kelas 2 titik pengukuran yaitu 01 dan O2. Dalam proses pengukuran, alat ukur Luxmeter diletakkan pada tiap titik pengukuran, dengan ketinggian $\pm 80 \mathrm{~cm}$, diukur secara manual dengan 1 alat yang dilakukan dalam kurun waktu tiap jamnya di semua titik pengukuran. Pengukuran ini berlangsung dari jam 8 pagi hingga jam 4 sore.

Luasan kedua kelasnya 6,15 m x 9 m yaitu 55,35 m², danbukaan di kedua sisi dinding kelasnya identik, dengan posisi kedua kelas yang saling berhadapan. Berikut adalah potongan sisi A dan sisi B dari kelas tersebut:

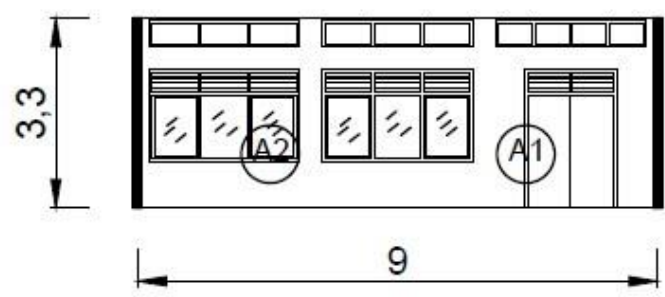

Gambar8.Potongan Sisi A (Pribadi, 2020) 


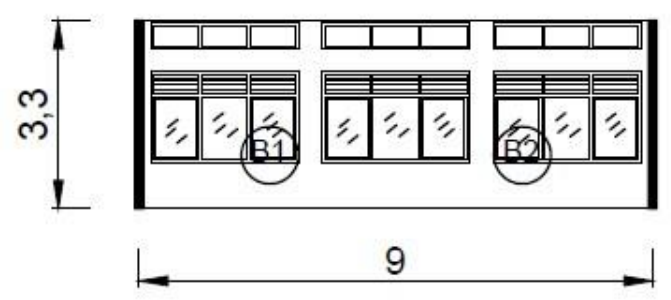

Gambar9.Potongan Sisi B (Pribadi, 2020)

Diketahui luas bukaan juga dapat mempengaruhi kenyamanan visual sebuah ruang(Sari, Nugroho, \& Sudarmo, 2017).

Dari luas dinding Ruang Kelas 1 dan Kelas 2 seluas $29 \mathrm{~m}^{2}$, terhitung sudah digunakan untuk bukaan jendela dengan ukuran 2,6 $\mathrm{m} \times 1,6 \mathrm{~m}$ atau 4,16 $\mathrm{m}^{2}$ dan 2,6 $\mathrm{m} \times 0,45$ matau $1,17 \mathrm{~m}^{2}$ dan pintu berukuran 1,6 $\mathrm{m} \times 2,4 \mathrm{~m}$ atau 3,84 $\mathrm{m}^{2}$, dengan jumlah semuanya sebesar $15,5 \mathrm{~m}^{2}$ atau sudah $53 \%$ bagian dindingnya digunakan untuk bukaan untuk sisi $A$, dan di sisi B sebesar $16 \mathrm{~m}^{2}$ atau sudah $55 \%$ terpakai untuk bukaan.

Di kelas 1, sisi A dan sisi B terhalang vegetasi dan bangunan, sedangkan di kelas 2 hanya sisi A yang terhalang vegetasi dan bangunan, dan sisi B tidak terlalu terhalang vegetasi maupun bangunan lainnya. Berikut adalah foto vegetasi yang menghalangi dilihat dari dalam kelas:
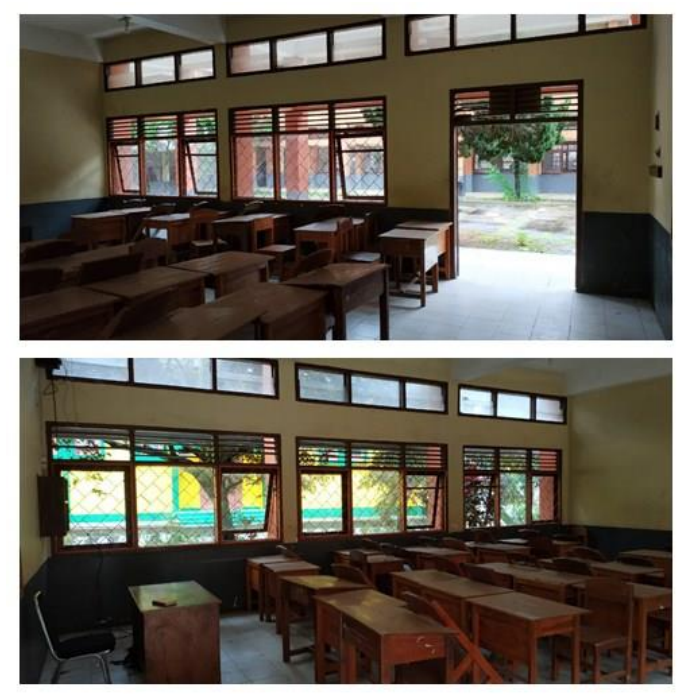

Gambar10.Vegetasi sekitar Ruang Kelas 1 (Foto Dokumentasi, 2020) 

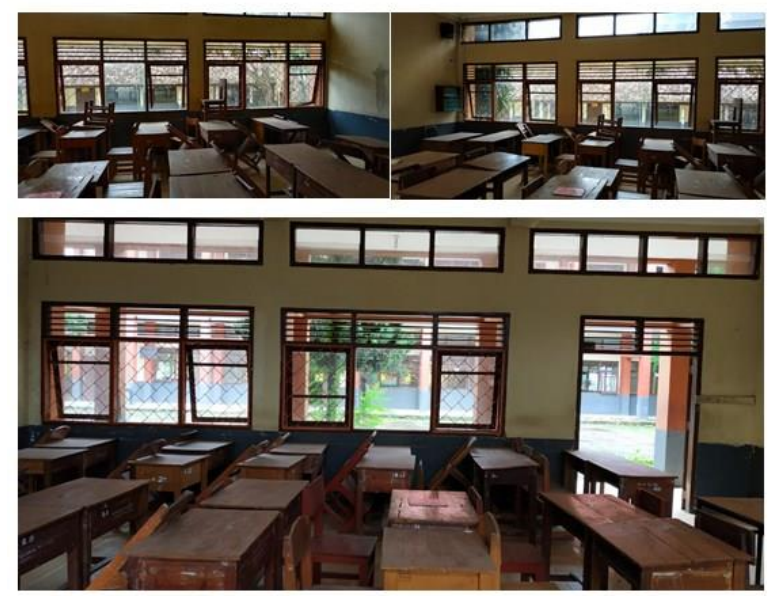

Gambar11.Vegetasi sekitar Ruang Kelas 2 (Foto Dokumentasi, 2020)

Pohon tersebut memiliki ketinggian antara 5 - 6 meter, melebihi dari tinggi ruang kelas yaitu 3,3 meter, dan juga bangunan sekitar kelas lebih tinggi dari kelas-kelas tersebut, sehingga baik bangunan maupun vegetasi sekitara yang ada cukup menghalangi pencahayaan yang masuk ke dalam kelas.Vegetasi tersebut menghalangi sisi dinding bagian B di Kelas 1 sebesar 21\%.

\section{Hasil dan Pembahasan}

Berikut adalah hasil dari pengukuran dari hari Senin hingga Jumat. Data pengukuran yang ditampilkan berikut merupakan data hasil jumlah dari tiap jamnya yang kemudian dicari rataratanya, dan mendapatkan hasil pengukuran di hari tersebut sebagai berikut:

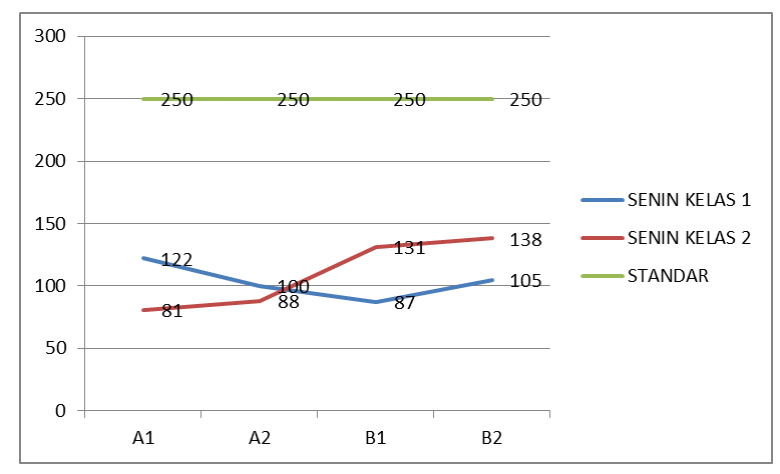

Gambar12.Grafik Pengukuran Senin, 16 November (Pribadi, 2020)

Grafik diatas adalah data rata-rata pengukuran tiap titik kedua ruang kelas di hari Senin 16 November 2020, dimana di saat pengkuran dilaksanakan juga terjadi cuaca hujan. Data ini menunjukan perbandingan besaran jumlah cahaya yang masuk di kedua ruang kelas, dimana Kelas 1 terdapat banyak vegetasi di salah satu sisinya sedangkan Kelas 2 tidak. Tidak ada pencahayaan yang memenuhi standar di hari ini. 


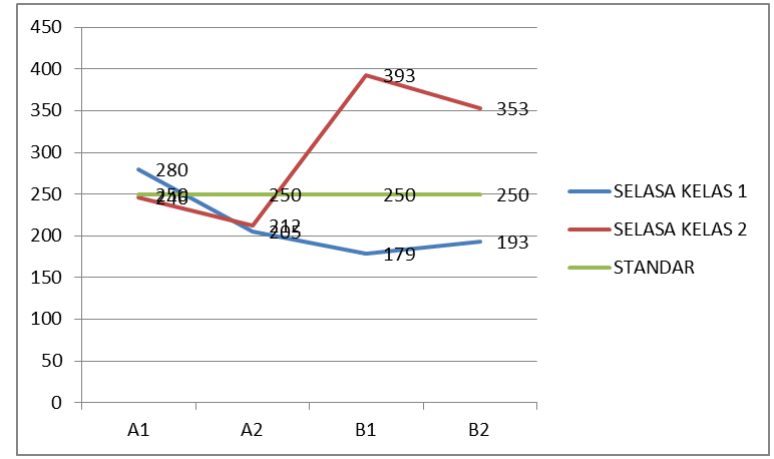

Gambar13.Grafik Pengukuran Selasa, 17 November 2020 (Pribadi, 2020)

Berikutnya adalah data pengukuran lux di hari Selasa 17 November 2020, terlihat mayoritas lux cahaya yang masuk ke ruang kelas hari ini jauh lebih baik dari hari Senin, dan beberapa titik kelas sudah memenuhi standar yang ada yaitu 250 lux, seperti pada Kelas 1 dan Kelas 2 pada titik A1 sudah mendekati standar pencahayaan alami ruang kelas, namun untuk Kelas 2 sisi B jauh melebihi standar.

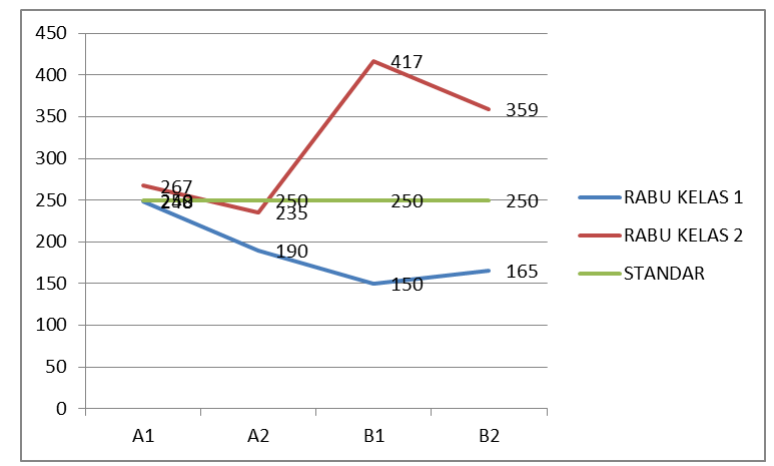

Gambar14.Grafik Pengukuran Rabu, 18 November 2020 (Pribadi, 2020)

Selanjutnya adalah data pengukuran di hari Rabu 18 November 2020. Di Kelas 1 hanya titik A1 saja yang sudah memenuhi standar pencahayaan ruang kelas, di Kelas 2 titik A1, A2, mendekati standar namun pada sisi B melebihi jauh dari standar pencahayaan ruang kelas.

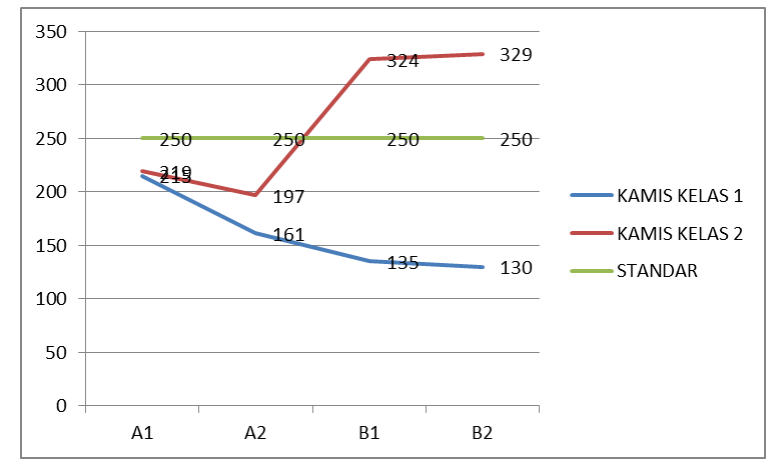

Gambar15.Grafik Pengukuran Kamis 19 November 2020 (Pribadi, 2020)

Diatas adalah denah data pengukuran di hari Kamis 19 November 2020. Terlihat, untuk kali ini belum ada yang memenuhi standar pencahayaan ruang kelas dengan baik. Pencahayaan yang melebihi standar terjadi di titik B1 dan B2 kelas, dan itu terlalu jauh dari toleransi standar pencahayaan. 


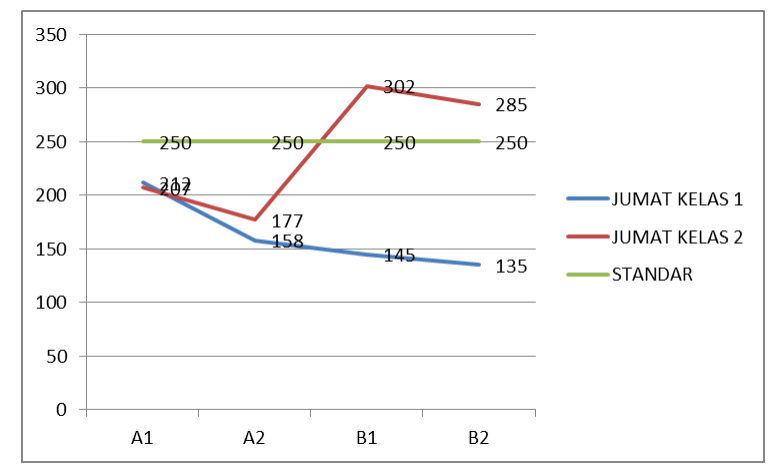

Gambar16.Grafik Pengukuran Jumat 20 November 2020 (Pribadi, 2020)

Dan ini adalah pengukuran rata-rata data lux di hari Jumat 20 November 2020. Untuk Kelas 1 tidak ada lagi yang memenuhi standar lux pencahayaan ruang kelas, sedangkan untuk Kelas 2, kedua titik yaitu B1 dan B2 memenuhi standar 250 lux penerangan untuk ruang kelas.

Dari penelitian lain di sebuah Sekolah Dasar yang terletak di perkotaan Manado (Wibowo, Kindangen, \& Sangkertadi, 2017)memiliki sebuah kasus yang sama, dimana pada salah satu ruang sampel kelas yang ditelitinya, memiliki dua sisi bukaan, yang keduanya terhalangi vegetasi. Namun pada sisi timur walaupun terhalang, cahaya yang masuk masih lebih baik karena ada jarak antara dinding dan vegetasi sehingga masih dapat Pantulan Eksternal (ERC) yang membuat ruang kelas tersebut mendapatkan cahaya yang lebih baik dibandingkan dengan sisi yang memiliki vegetasi yang rapat dan dekat dengan bangunan sehingga susah mendapatkan ERC. Penelitian ini menunjukkan bahwa vegetasi yang di dekat bukaan objek penelitian memang mempengaruhi pencahayaan.

Dari hasil penelitian di atas selama seminggu dari hari Senin hingga Jumat, diketahui:

Di Kelas 1 titik paling nyaman terdapat pada titik A1 yang dimana merupakan bagian dari depan kelas yang dekat dengan pintu masuk, mengalami tingkat pencahayaan paling tinggi sebesar 280 lux dan paling rendah 122 lux. Sedangkan titik paling tidak nyaman terdapat pada titik B1 yang merupakan sisi berlawanan dari sisi pintu, dengan lux tertinggi hanya mencapai 179 lux dan paling rendah 87 lux.

Dan untuk Kelas 2 titik paling nyaman untuk belajar terletak di titik A1, yaitu dengan nilai lux tertinggi 267 lux dan terendah sebesar 81 lux. Untuk titik tidak nyaman, yang memiliki pencahayaan berlebih adalah titikB1, dengan lux tertinggi 417 lux dan terendah 131 lux, dan yang mengalami kurang pencahayaan berada di titik A2, dengan nilai tertinggi 235 lux dan nilai terendah 88 lux.

Dari kedua perbandingan itu, maka diketahui bahwa pepohonan dan bangunan di sekitar ruang kelas juga mempengaruhi terhadap masuknya pencahayaan alami ke dalam kelas, karena terlihat Kelas 1 yang salah satu sisinya terdapat banyak pepohonan dan bangunan tinggi, yaitu titik B1 dan B2 tidak dapat memenuhi standar ruang kelas dan hanya di titik A1 saja yang memenuhi standar kenyamanan, sedangkan di Kelas 2 yang tidak terdapat banyak vegetasi dan bangunan di sisi B1 dan B2 mengalami pencahayaan yang berlebih dan tidak nyaman untuk belajar, dan titik paling nyaman terdapat di titik $\mathrm{A} 1$ atau titik yang di dekat dengan pintu masuk kelas. 


\section{Kesimpulan}

Dari pengamatan penelitian, didapati kesimpulan yaitu suasana Ruang Kelas pada saat pengukuran tidak adanyakegiatan, sehingga penelitian ini hanya dilakukan melalui pengukuran dan pengamatan. Dalam masa penelitian keadaan iklim yang terjadi disana adalah panas dan terkadang hujan di pagi, siang, dan sore hari, yang mempengaruhi nilai pencahayaan sehingga pada saat itu membuat besar cahaya yang masuk ke ruang kelas lebih kecil.

Beberapa faktor yang mempengaruhi pencahayaan di Ruang Kelas diantaranya berupa cuaca, bangunan dan vegetasi sekitar. Ruang Kelas 1 yang terdapat banyak vegetasi mengalami kekurangan pencahayaan dibandingkan dengan Ruang Kelas 2 yang tidak terdapat banyak vegetasi yang mengalami pencahayaan berlebih. Vegetasidi sekitarRuangKelas1 berupa pohon yang memiliki ketinggian hingga $6 \mathrm{~m}$, lebih tinggi dari ruang kelas, dan di sisi B nya terdapat banyak dan berdekatan dengan dinding sehingga menghalangi sisi ruang kelas tersebut sebesar $\pm 21 \%$.

Hasilnya, sisi paling nyaman untuk belajar di kedua kelas tersebut adalah titik A1, dengan Kelas 1 A1 nilai cahaya tertingginya adalah 280 lux dan terendahnya 122 lux, dan Kelas 2 A1 nilai cahaya tertingginya 267 lux dan terendah 81 lux. Titik paling tidak nyaman dibawah standar di Kelas 1 adalah titik B1 dengan pencahayaan tertinggi hanya 179 lux dan terendah 87 lux sedangkan di Kelas 2 adalah titik A2 dengan nilai cahaya tertinggi 235 lux dan terendah 88 lux. Untuk titik paling tidak nyaman melebihi standar ada di Kelas 2 pada titik B1 dengan pencahayaan tertinggi sebesar 417 lux dan terendah 131 lux.

Kesimpulannya, mayoritas pencahayaan di ruang kelas ini masih tidak memenuhi standar, karena terdapat banyak pencahayaan yang belum memenuhi standar atau melebihi standar kenyamanan pencahayaan ruang kelas yang ditetapkan. Penelitian lebih lanjut diperlukan untuk mengetahui solusi yang dibutuhkan agar ruangkelas tersebut dapat memenuhi standar yang ada.

\section{Daftar Pustaka}

Amin, S., Jamala, N., \& Luizjaya, J. (2016). Analisis Pencahayaan Alami pada Ruang Kuliah Fakultas Teknik Universitas Hasanuddin. 7-12.

Bakmohammadi, P., \& Noorzai, E. (2020). Optimization of the design of the primary school classrooms in terms of energy and daylight performance considering occupants ' thermal and visual comfort. Energy Reports, 6, 1590-1607. https://doi.org/10.1016/j.egyr.2020.06.008

Kasiram, M., \& Idris, M. (2010). Metodologi penelitian kualitatif-kuantitatif. Malang: UIN Maliki Press.

Min, M. (2016). Jenis Jenis Metode dalam Penelitian Kuantitatif dan Pengertian Terlengkap.

Noda, L., Lima, A. V. P., Souza, J. F., Leder, S., \& Quirino, L. M. (2020). Thermal and visual comfort of schoolchildren in air-conditioned classrooms in hot and humid climates. Building and Environment, 107156. https://doi.org/10.1016/j.buildenv.2020.107156

Sari, D. L., Nugroho, A. M., \& Sudarmo, B. S. (2017). Pengaruh Window-to-Wall Ratio Terhadap 
Analisis Kenyamanan Pencahayaan Alami di Ruang Kelas SMKN 2 Bandar Lampung

Kenyamanan Visual Pada Apartemen Mahasiswa di Surabaya.

SNI. (2000). Konservasi energi pada sistem pencahayaan.

Tongkukut, S. H. J. (2016). Analisis Tingkat Pencahayaan Ruang Kuliah Dengan Memanfaatkan Pencahayaan Alami Dan Pencahayaan Buatanklorofil Pada Beberapa Varietas Tanaman eum a Jurusan. 5(2), 108-112.

Wibowo, R., Kindangen, J. I., \& Sangkertadi. (2017). Sistem pencahayaan alami dan buatan di ruang kelas sekolah dasar di kawasan perkotaan. Sistem Pencahayaan Alami Dan Buatan Di Ruang Kelas Sekolah Dasar Di Wilayah Perkotaan, (1), 87-98.

Yuniar, E., Dwicahyo, S., Harmanda, S. J., Putra, D. K., \& Wijaya, F. R. (2014). Kajian Pencahayaan Alami pada Bangunan Villa Isola Bandung. 2(1). 
Farhan Giano Indrakesuma, Ai Siti Munawaroh 